Japan. J. Breed., $36: 390 \sim 400$ (1986)

\title{
Genetic Analysis of Subunits of Two Major Storage Proteins $(\beta$-Conglycinin and Glycinin) in Soybean Seeds
}

\author{
Yoshihiro Tsukada ${ }^{1)}$, Keisuke Kitamura ${ }^{1)}$, Kyuya Harada $^{21}$ \\ and Norihiko Kaizuma ${ }^{1)}$ \\ 1) Faculty of Agriculture, Irate University, Morioka, $\bar{\top} 020$ \\ 2) National Institute of Agrobiological Resources, Yatabe, \\ Tsukuba, $\bar{T} 305$
}

\begin{abstract}
Eight hundred and fifty soybean accessions were screened for genotypes with electrophoretic variations of the $\beta$-conglycinin and glycinin subunits. We detected two abnormal SDS-gel electrophoretic forms of $\beta$-conglycinin $\alpha$-subunit, the slow electrophoretic mobility type designated as $\alpha$-slow-type and the low $\alpha$-subunit content type designated as $\alpha$-low-type. Each of these two forms was controlled by a codominant allele at a single locus. The gene symbol $C g y_{2}{ }^{a}$ was assigned to the common type and $C g y_{2}{ }^{b}$ to the $\alpha$-slow-type. We found a new electrophoretic form of $\beta$-conglycinin $\beta$-subunit designated as $\beta^{\prime}$-subunit which migrates slightly faster than the $\beta$-subunit on SDS-gels. Beta-prime $\left(\beta^{\prime}\right)$ subunit was controlled by a single dominant gene designated as $C g y_{3}$. The homozygous recessive $c g y_{3} c g y_{3}$ lacked the $\beta^{\prime}$-subunit. We observed two variations of the glycinin group-I acidic subunits $\left(A_{1}, A_{2}\right.$ and $\left.A_{3}\right)$ by alkaline urea electrophoresis, i. e., the concomitantly slow and fast electrophoretic mobility types designated as A(I)slow-type and $A(I)$-fast-type, respectively. The concomitantly slow and fast migrating $A_{1}, A_{2}$ and $A_{3}$ subunits, respectively, behaved in the $F_{2}$ seeds as a single block composed of the three electrophoretic bands. Each of these electrophoretic forms was inherited as if controlled by a codominant allele at a single locus. The gene symbols, $G y_{\mathrm{I}}^{\mathrm{a}}, G y_{\mathrm{I}}{ }^{\mathrm{b}}$ and $G y_{\mathrm{I}}{ }^{c}$ were assigned to the alleles for the common electrophoretic type, the A(I)-slowtype and the A(I)-fast-type, respectively. Close linkage was found between $C g y_{2}$ and $C g y_{3}$. The gene $C g y_{1}$ controlling the $\beta$-conglycinin $\alpha^{\prime}$-subunit was independent of $G y_{\text {I }}$ and $G y_{4}$ which controls the $\mathrm{A}_{5}$ subunit and its associated basic subunit.
\end{abstract}

KEY WORDS : Glycine max, storage protein subunits, $\beta$-conglycinin, glycinin, inheritance, genetic linkage.

\section{Introduction}

Soybean seeds contain 35 40\% protein on a dry weight basis, about $70 \%$ of which consists of two major storage globulins (Derbyshire et al. 1976), $\beta$-conglycinin (M. W. = 150,000) and glycinin (M.W.=350,000). Beta-conglycinin which is a glycoprotein containing mannose and glucosamine is composed of six isomers with varying proportions of three kinds of subunits $\left(\alpha, \alpha^{\prime}\right.$ and $\beta$ ) (Thanh and Shrbasaki 1976, 1977). On the other hand, glycinin is an oligomeric protein composed of several acidic and basic subunits, where specific pairs of acidic and basic subunits are linked through disulfide bonds (Kitamura et al. 1976. Moreira et al. 1979, Iyenger and Ravestein 1981).

Some electrophoretic variations of storage proteins in pea and common bean were reported (CASEY 1979, Hall et al. 1977, Brown et al. 1981 a), and the inheritance of the variations and linkage among the genes of these storage proteins have been partially revealed (Matta and Gatehouse 1982, Mahmoud and Gatehouse 1984, Brown et al. $1981 \mathrm{~b})$. As for the storage proteins in soybean, some electrophoretic variations

\footnotetext{
Received April 7, 1986.
} 
of the glycinin subunits on polyacrylamide gels containing urea (Kitamura et al. 1980, MoRi et al. 1981) and two mutant strains of the $\beta$-conglycinin subunits in SDS-gels (Kitamura and Kaizuma 1981) were reported. Recently, the primary structures of soybean storage proteins have been revealed by amino acid sequencing and by sequencing cDNAs.

However, as yet, only a few studies have been performed on the inheritance and linkage for $\beta$-conglycinin (Kitamura et al. 1984, Davies et al. 1985) and glycinin (Harada et al. 1983) subunit genes.

In this study, we attempted to identify genotypes showing electrophoretic variations of the $\beta$-conglycinin and glycinin subunits and analyzed the inheritance of the variations. Furthermore, we determined whether there are linkages among the genes coding these storage protein subunits.

\section{Materials and Methods}

Soybean accessions preserved in our laboratory were used for the screening of electrophoretic variations. Part of the soybean accessions (shown in Table 1) was grown and harvested at the Iwate University Experimental Farm or in a greenhouse in 1982 and 1983. Crosses among the electrophoretic variants shown in Table 2 were made in the summer of 1983 . The $F_{2}$ seeds were obtained by selfing of $F_{1}$ plants grown in the greenhouse. The $\mathrm{F}_{3}$ seeds from the cross between Keburi and Moshidou

Table 1. Electrophoretic variations and their gene symbols of storage protein subunits

\begin{tabular}{|c|c|c|c|c|c|}
\hline & \multirow{3}{*}{ Accessions } & \multicolumn{4}{|c|}{ Variations } \\
\hline & & \multicolumn{2}{|c|}{$\beta$-conglycinin } & \multicolumn{2}{|l|}{ Glycinin } \\
\hline & & subunit(s)-type & gene symbol & subunit(s)-type & gene symbol \\
\hline 1. & Raiden & $\alpha$-common-type & $\mathrm{Cg} y_{2}{ }^{\mathrm{a}}$ & $A(I)$-common, $A_{4}$-type & $G y_{\mathrm{I}}^{\mathrm{a}}, g y_{4}$ \\
\hline 2. & Moshidou Gong 503 & $\alpha-, \beta$-low-type & - & $A(I)$-fast, $A_{5}$-type & $G y_{\mathrm{I}} \mathrm{c}, G y_{4}$ \\
\hline 3. & Keburi & $\alpha^{\prime}-$ less-type & $\operatorname{cg} y_{1}$ & $A(I)-$ common, $A_{5}$-type & $G y_{\mathrm{I}}^{\mathrm{a}}, \quad G y_{4}$ \\
\hline 4. & Iwate No. 1 & $\beta^{\prime}-$ type & $C g y_{3}$ & $A(I)$-common, $A_{5}$-type & $G y_{\mathrm{I}}^{\mathrm{a}}, \quad G y_{4}$ \\
\hline 5. & Tohzan Kei BL 51 & $\beta^{\prime}$-type & $C g y_{3}$ & $A(I)$-common, $A_{4}$-type & $G y_{\mathrm{I}}^{\mathrm{a}}, \quad g y_{4}$ \\
\hline 6. & Mikuriya Shiro & $\beta^{\prime}$-type & $\mathrm{Cg}_{3}$ & $A(I)-$ common, $\quad A_{5}$-type & $G y_{\mathrm{I}}^{\mathrm{a}}, \quad G y_{4}$ \\
\hline 7. & Zairai Aki Daizu & $\alpha$-slow-type & $C g y_{2}{ }^{b}$ & $A(I)$-common, $A_{5}$-type & $G y_{\mathrm{I}}^{\mathrm{a}}, G y_{4}$ \\
\hline 8. & Oh-oka Zairai & $\alpha$-slow-type & $C g y_{2}{ }^{\mathrm{b}}$ & $A(I)-$ common, $A_{5}$ type & $\mathrm{Gy}_{\mathrm{I}}^{\mathrm{a}}, \quad G y_{4}$ \\
\hline 9. & PI 54608-1 & $\alpha$-slow-type & $C g y_{2}{ }^{b}$ & $A(I)$-common, $\quad A_{5}$-type & $G y_{\mathrm{I}}^{\mathrm{a}}, G y_{4}$ \\
\hline 10. & PI 90763 & $\alpha$-low-type & - & $A(I)$-slow, $A_{5}$-type & $G y_{I^{b}}, G y_{4}$ \\
\hline 11. & PI 253651-A & $\alpha$-low-type & - & $A(I)$-slow, $A_{5}$-type & $G y_{\mathrm{I}}^{\mathrm{b}}, G y_{4}$ \\
\hline
\end{tabular}

Table 2. Cross combinations and marker genes
A. Keburi $\left(c g y_{1}, C g y_{2}{ }^{\mathrm{a}}\right) \times$ PI $54608-1\left(C g y_{1}, C g y_{2} \mathrm{~b}\right)$
B. Iwate No. $1\left(C g y_{2}{ }^{\mathrm{a}}, C g y_{3}\right) \times$ Zairai Aki Daizu $\left(C g y_{2}{ }^{\mathrm{b}}, \operatorname{cg} y_{3}\right)$
C. Tohzan Kei BL $51\left(C g y_{2}{ }^{\mathrm{a}}, C g y_{3}, g y_{4}\right) \times$ Oh-oka Zairai $\left(C g y_{2}{ }^{\mathrm{b}}, c g y_{3}, G y_{4}\right)$
D. Mikuriya Shiro $\left(\mathrm{Cgy}_{3}, G y_{\mathrm{I}}^{\mathrm{a}}\right) \times \mathrm{PI} 253651-\mathrm{A}\left(\mathrm{cg} y_{3}, G y_{\mathrm{I}}^{\mathrm{b}}\right)$
E. PI $54608-1\left(C g y_{2}^{\mathrm{b}}, G y_{\mathrm{I}}^{\mathrm{a}}\right) \times$ PI $90763\left(C g y_{2}{ }^{\mathrm{a}}, G y_{\mathrm{I}}^{\mathrm{b}}\right)$
F. Raiden $\left(\mathrm{Cgy}_{2}{ }^{\mathrm{a}}, g y_{4}\right) \times$ PI 54608-1 $\left(\mathrm{Cgy}_{2}^{\mathrm{b}}, G y_{4}\right)$
G. Keburi $\left(c g y_{1}, G y_{\mathrm{I}}^{\mathrm{a}}\right) \times$ Moshidou Gong $503\left(C g y_{1}, G y_{\mathrm{I}}^{\mathrm{c}}\right)$ 
Gong 503 were obtained by selfing of $F_{2}$ plants grown at the farm in 1984 .

In screening for the genotypes with electrophoretic variations of the major subunits of the $\beta$-conglycinin and glycinin proteins, the seed proteins were analyzed by sodium dodecyl sulfate (SDS) slab polyacrylamide gel electrophoresis (PAGE) according to the method of LaEmmli (1970) and slab alkaline urea (AU) system PAGE according to the method of Kitamura and Shibasaki (1975). It is easy to identify the major subunits of the $\beta$-conglycinin and glycinin proteins because the major electrophoretic bands of these subunits can be stained very strongly with Coomassie Brilliant Blue on the gels. To determine whether the variations detected are genuine or not, the isolated soybean globulin fraction was analyzed by two dimensional (2-D) electrophoresis based on the DAvis (1964) disc polyacrylamide gel system followed by the SDS- or AU-slab polyacrylamide gel system, as described previously (KiTAmura et al. 1980). The soybean globulin fraction was prepared from seed meal by isoelectric precipitation at $\mathrm{pH} 4.5$ in the buffer solution ( $0.05 \mathrm{M}$ Tris- $\mathrm{HCl}$ ).

Individual $\mathrm{F}_{2}$ and $\mathrm{F}_{3}$ seeds were crushed in coin envelops with a hammer except for the cross between Keburi and Moshidou Gong 503, in which the distal portions (about $10 \mathrm{mg}$ ) of the $\mathrm{F}_{2}$ seeds were cut off with a razor blade and crushed. The seed proteins were analyzed by the SDS- and AU-slab PAGE.

\section{Results and Discussion}

\section{Electrophoretic variations of $\beta$-conglycinin}

Figure 1 shows the electrophoretic variations of the $\beta$-conglycinin subunits on the SDS-gel : lane 1 corresponds to Raiden (common-type), lane 2 and 3 to Moshidou Gong 503 and Keburi, respectively (Kitamura and Kaizuma 1981), lane 4 corresponds to the variant having an extra $\beta^{\prime}$-subunit band which migrates slightly faster than the $\beta$-subunit, lane 5 corresponds to the variant having the subunit $\alpha_{\text {s }}$ with a slow electrophoretic mobility designated as $\alpha$-slow-type, and lane 6 to the variant having a low content of $\alpha$-subunit designated as $\alpha$-lowtype. Of 850 accessions screened, four were found to belong to the $\beta^{\prime}$-subunit, seven to the $\alpha$-slow-type, and ten to the $\alpha$-low-type.

Quantitative variations of the $\beta$-conglycinin $\beta$-subunit were observed, whereas no qualitative variations were detected. Genetic analysis of the $\beta$-subunit

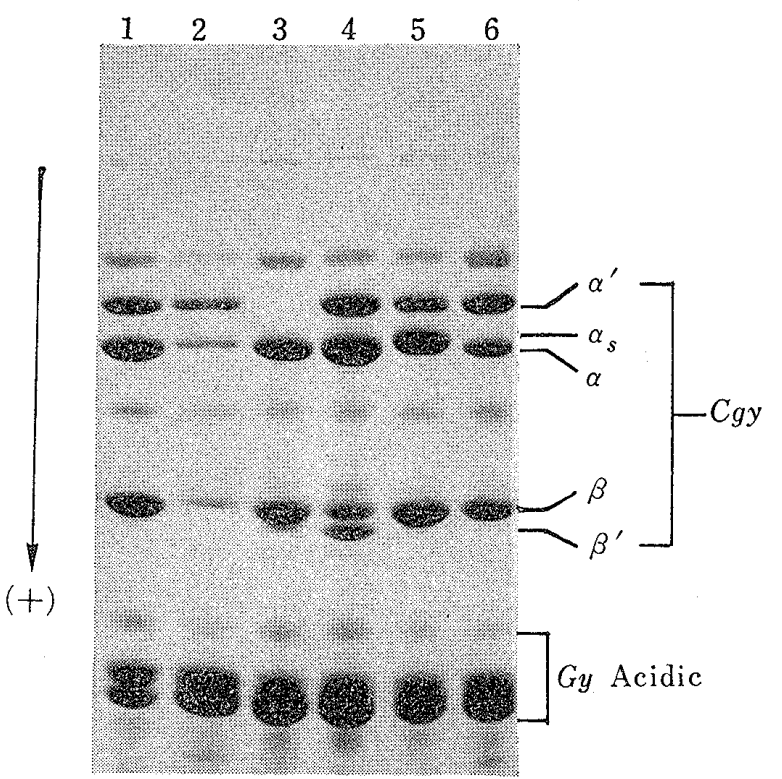

Fig. 1. SDS slab PAGE of $\beta$-conglycinin subunit bands from the six soybean accessions. 1: Raiden, 2 : Moshidou Gong 503, 3 : Keburi, 4: Mikuriya Shiro, 5 : Oh-oka Zairai, 6 : PI 90763. Soybean flour ( $10 \mathrm{mg}$ ) was suspended in $1 \mathrm{~m} l$ of $0.05 \mathrm{M}$ Tris $-\mathrm{HCl}$ ( $\mathrm{pH} 8.0$ ) containing $0.2 \% \mathrm{SDS}, 6 \mathrm{M}$ urea and $0.2 \mathrm{M} 2$-mercaptoethanol. Protein samples (about $10 \mu l)$ were electrophoresed with a constant voltage of about $125 \mathrm{~V}$ for $5 \mathrm{hr}$. The gel $(7.5 \%)$ was stained with Coomassie Brilliant Blue R-250. Cgy : $\beta$ conglycinin. Gy : glycinin. 
gene(s) was very difficult because the quantitative variations of this subunit were associated with changes of the environmental conditions.

Two possible explanations for the difference in the electrophoretic mobility of the $\alpha$-subunit on the SDS-gel can be proposed, i. e., 1) a difference in the number of amino acid residues and 2) a difference in the amino acid substitutions. A mutation which alters a signal peptidase recognition site may cause a difference in the number of amino acid residues because the $\alpha$-polypeptide chain is synthesized as a precursor with a slightly larger molecular weight (Tumer et al. 1981). Amino acid substitutions in the $\alpha$-polypeptide chain may also lead to differences in the electrophoretic mobility because such substitutions in certain polypeptides were found to change the electrophoretic mobility on the SDS-gel (De Jong et al. 1978, Noel et al. 1979).

\section{Electophoretic variations of glycinin}

ScAlion et al. (1985) divided the five glycinin subunits into group- I ( $\mathrm{A}_{1 \mathrm{a}} \mathrm{B}_{2}, \mathrm{~A}_{1 \mathrm{~b}} \mathrm{~B}_{1 \mathrm{~b}}$, $\left.A_{2} B_{1 a}\right)$ and group-II $\left(A_{3} B_{4}, A_{5} A_{4} B_{3}\right)$ based on the molecular size and degree of sequence homology. According to their designation, the $A_{1}, A_{2}$ and $A_{3}$ subunit (polypeptides) were treated as group- $I$ acidic subunits since the group including the $A_{1}, A_{2}$ and $A_{3}$ polypeptides and that including the $A_{4}$ and $A_{5}$ polypeptides correspond to the polypeptides referred to as group-I $\left(A_{1 a}, A_{1 b}, A_{2}\right)$ and group-II $\left(A_{3}, A_{4}\right)$, respectively.

Figure 2 shows the electrophoretic variations of the glycinin acidic subunits on the

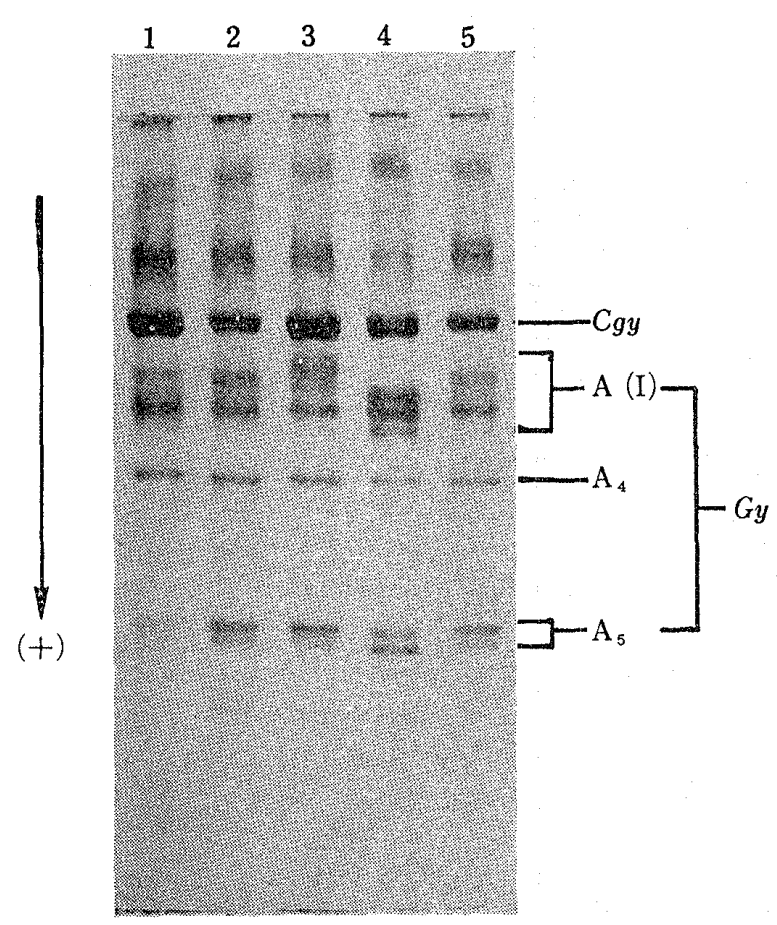

Fig. 2. AU slab PAGE of glycinin acidic subunits from the five soybean accessions. 1 : Radiden, 2 : Keburi, 3 : PI 90763, 4 : Moshidou Gong 503, 5 : Keburi. Soybean flour ( $10 \mathrm{mg}$ ) was suspended in $1 \mathrm{ml}$ of $0.05 \mathrm{M}$ Tris- $\mathrm{HCl}(\mathrm{pH} 8.0)$ containing $8 \mathrm{M}$ urea and $0.2 \mathrm{M} 2$-mercaptoethanol. Protein samples (about $10 \mu \mathrm{l})$ were electrophoresed with a constant current of about $15 \mathrm{~mA}$ for $6 \mathrm{hr}$.
AU-gel : lane 1 and 2 correspond to the $\mathrm{A}_{4}$ and $\mathrm{A}_{5}$ glycinin type respectively (Kitamura et al. 1980, Harada et al. 1983), lane 3 and 4 indicate electrophoretic variations in which the $A_{1}, A_{2}$ and $A_{3}$ subunits migrate concomitantly slower and faster than the normal group- I acidic subunits, respectively. The slow and fast-migrating group-I acidic subunits showed the same electrophoretic mobility as that of the normal group-I acidic subunits on the SDS-gel. We designated the concomitantly slow and fast electrophoretic mobility types as $A(I)-$ slow-type and $A(I)$-fast-type, respectively.

CASEy et al. (1979, 1981) reported that there were considerable genetic variations. in the type and number of legumin acidic subunits, and the amount of the total sulfur-containing amino acids of the purified legumin variants ranged from. 1.09 to $1.75 \mathrm{~mol} \%$. It is suggested that the amount of total sulfur-containing, 
amino acids varied among the four subunit types detected in this investigation.

Two dimensional electrophoresis

Two dimensional PAGE (disc PAGE $\times$ SDS- or AU-slab PAGE) was performed to determine whether the electrophoretic variants of the $\beta$-conglycinin and glycinin subunits which were detected were genuine or not. It is possible to separate $\beta$-conglycinin and glycinin by disc gel electrophoresis because glycinin migrates over a greater distance than $\beta$-conglycinin, and few other soybean proteins migrate to the positions corresponding to the two proteins (Hill and Breidenbach 1974).
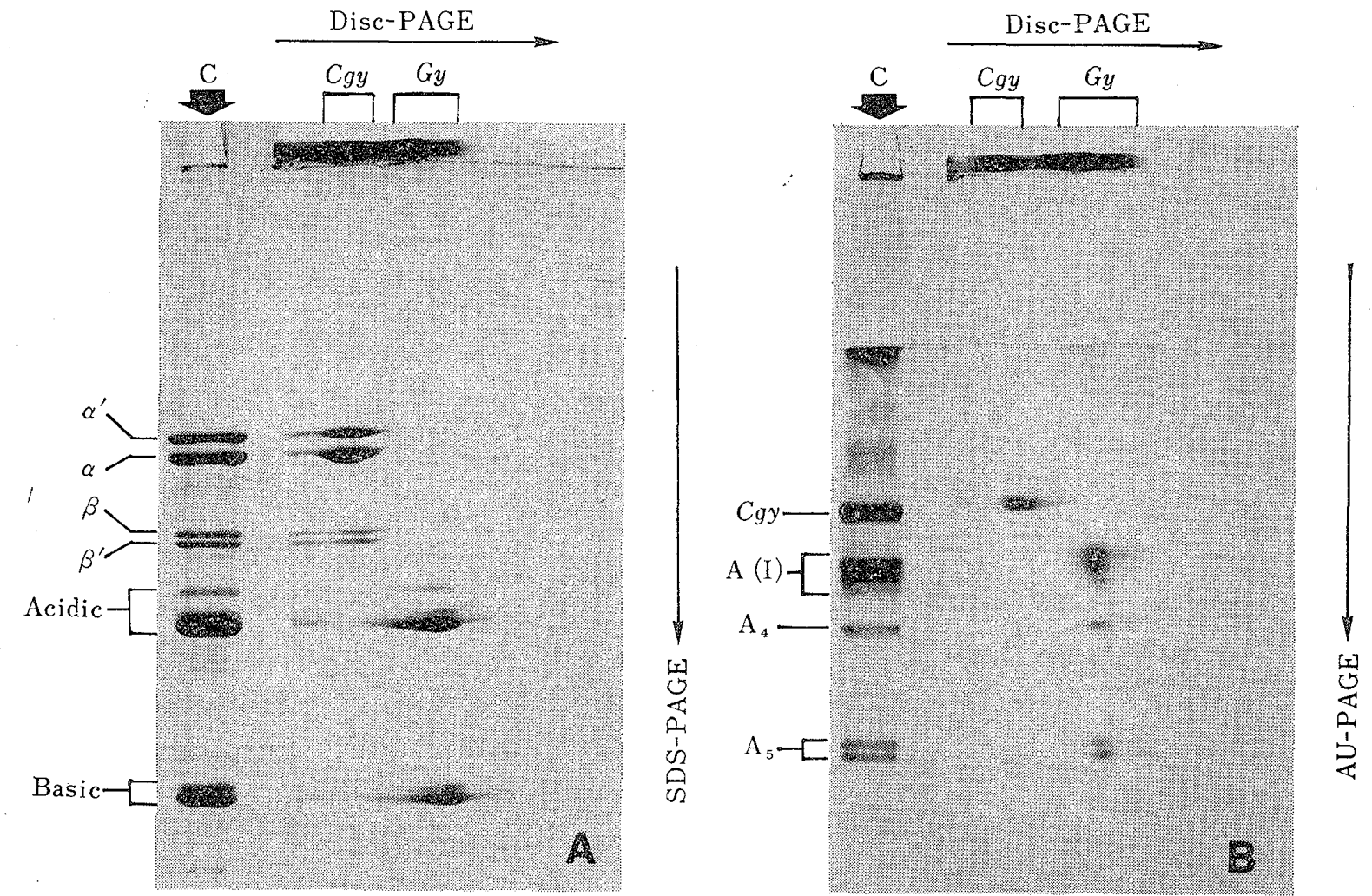

Fig. 3. 2-D PAGE of the soybean globulin fractions (A : Mikuriya Shiro and B: Moshidou Gong 503) using the disc PAGE in the first dimension and the SDS slab PAGE (A) or the AU slab PAGE (B) in the second dimension. Protein sample $(20 \mu l$, ca. $0.1 \%$ in $35 \mathrm{mM}$ potassium phoshate buffer, $\mathrm{pH}$ containing $0.4 \mathrm{M} \mathrm{NaCl}$ and $0.2 \mathrm{M} 2$-mercaptoethanol) was electrophoresed with a constant current of $1 \mathrm{~mA}$ per tube for $2 \mathrm{hr}$ in the first dimension. After incubation of the disc gel in an excess amount of the sample buffer, the gel was layered on the second dimensional gel, Electrophoretic conditions in the second dimension were the same as those outlined in Fig. 1 and 2 , except for the concentration of acrylamide $(7.5 \% \sim 15 \%)$ on the SDS slab PAGE. C : control lane (globulin fraction).

Figure 3 shows that the globulin fractions from the variants separated in the first dimension gave banding patterns in the second dimension similar to those of the control lane: the $\beta^{\prime}$-subunit band behaved as the $\beta$-conglycinin subunit (A), and the fast-migrating group-I acidic subunits bahaved as the glycinin subunits (B). Similar results were obtained using the soybean globulin fractions from the $\alpha$-slow-type and A ( I )-slow-type. The globulin fractions from the accessions (shown in Table 1) grown in 1982 gave banding patterns of $\beta$-conglycinin and glycinin subunits identical with those of the accessions grown in 1983 : the subunit patterns were consistent, regardless 
of the environments in which the plants were grown.

These results demonstrate that the $\beta^{\prime}$-subunit is a genuine subunit of $\beta$-conglycinin, and that the group-I acidic subunits of the $A(I)$-fast-and $A(I)$-slow-type soybean are also genuine glycinin acidic subunits.

\section{Inheritance of $\beta$-conglycinin}

The $\mathrm{F}_{1}$ seeds from crosses between $\alpha$-common-type and $\alpha$-slow-type (Table $2 \mathrm{~A}, \mathrm{~B}$, $\mathrm{C}, \mathrm{E}$ and $\mathrm{F}$ ) contained the $\alpha$ - and $\alpha_{\mathrm{s}}$-subunit bands. In the $\mathrm{F}_{2}$ seeds a $1: 2: 1$
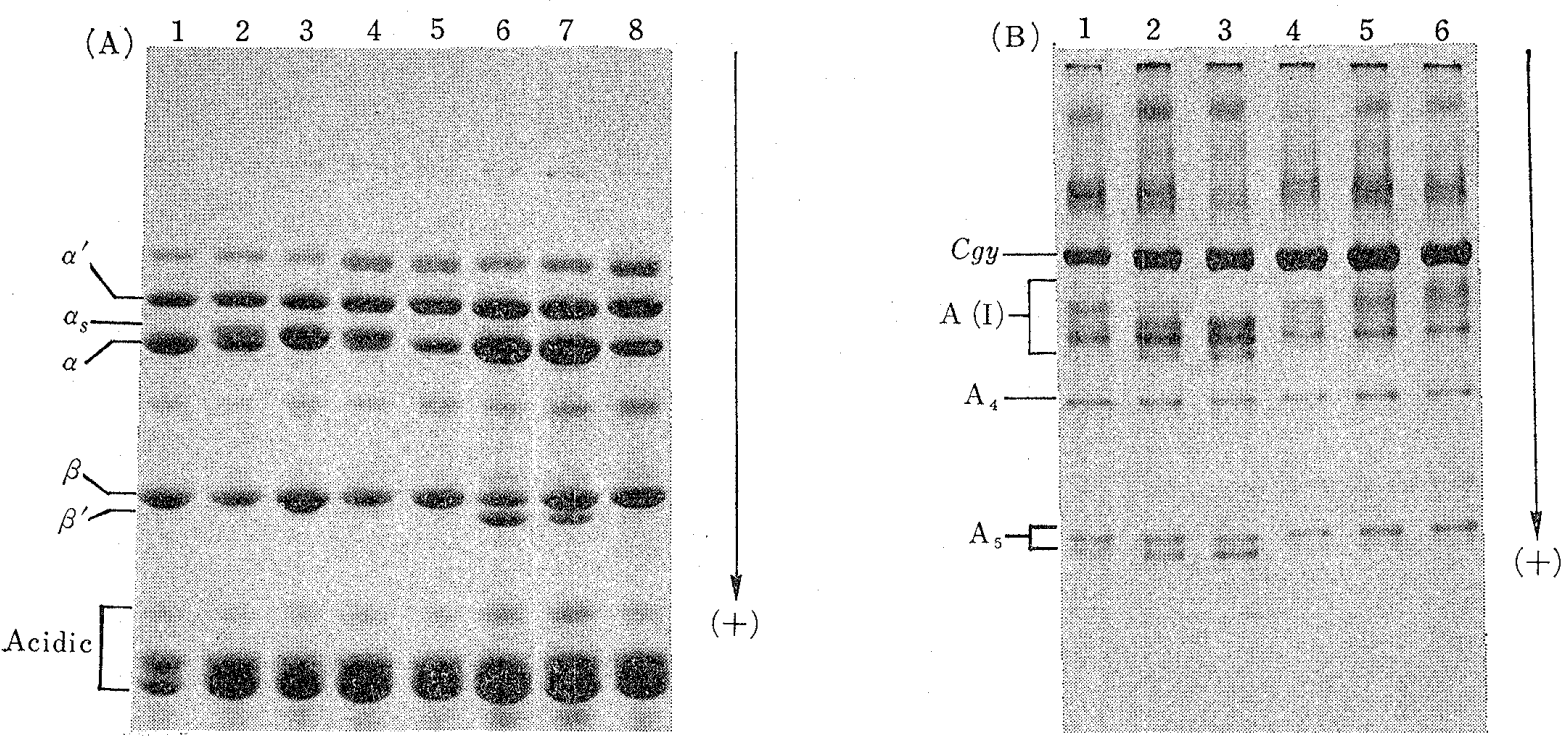

Fig. 4. (A) SDS slab PAGE of the $F_{2}$ progeny for the $\beta$-conglycinin subunit patterns. 1: common-type from the cross $F, 2: F_{1}$-type from the cross $F$, $3: \alpha$-slow-type from the cross E, $4: F_{1}$-type from the cross E, $5: \alpha$-lowtype from the cross $E, 6: \beta$-type from the cross $D, 7: F_{1}$-type from the cross $D, 8: \alpha$-low-type from the cross $D$.

(B) $\mathrm{AU}$ slab PAGE of the $\mathrm{F}_{2}$ progeny for the glycinin acidic subunit patterns. 1:A(I)-common-type from the cross $G, 2: F_{1}$-type from the cross G, 3:A(I)-fast-type from the cross G, 4:A(I)-common-type from the cross D, $5: F_{1}$-type from the cross D, $6: A(I)$-slow-type from the cross D. Cross combinations are shown in Table 2, Electrophoretic conditions were the same as those outlined in Fig. 1 and 2.

Table 3. Observed and expected $\mathrm{F}_{2}$ segregation from five crosses for the electrophoretic bands of the $\beta$-conglycinin $\alpha$-subunit

\begin{tabular}{ccccccc}
\hline \multirow{2}{*}{ Cross } & \multicolumn{5}{c}{ Genotype } & $\chi^{2}$ \\
\cline { 3 - 6 } & & $C g y_{2}{ }^{\mathrm{a}} C g y_{2}{ }^{\mathrm{a}}$ & $C g y_{2}{ }^{\mathrm{a}} C g y_{2}{ }^{\mathrm{b}}$ & $C g y_{2}{ }^{\mathrm{b}} C g y_{2}{ }^{\mathrm{b}}$ & $(1: 2: 1)$ & $\mathrm{P}$ \\
\hline A. & Obs. & 77 & 101 & 55 & 8.28 & 0.01 \\
& Exp. & 58.25 & 116.5 & 58.25 & & \\
B. & Obs. & 27 & 81 & 36 & 3.38 & 0.1 \\
& Exp. & 36 & 72 & 36 & & \\
C. & Obs. & 34 & 70 & 40 & 0.61 & 0.7 \\
& Exp. & 36 & 72 & 36 & & \\
E. & Obs. & 11 & 21 & 11 & 0.03 & 0.98 \\
& Exp. & 10.75 & 21.5 & 10.75 & & \\
F. & Obs. & 19 & 50 & 20 & 1.48 & 0.3 \\
& Exp. & 23 & 46 & 23 & & \\
\hline
\end{tabular}


ratio of the $\alpha$-common-type $: F_{1}$-type $: \alpha$-slow-type patterns was obtained (Fig. 4 , Table 3). From these results, we conclude that the $\alpha$-subunit bands are controlled by codominant alleles as a sigle locus. The gene symbols $C g y_{2}{ }^{a}$ and $C g y_{2}{ }^{b}$ were assigned to the $\alpha$-common-type and the $\alpha$-slow-type, respectively.

Electrophoretic analysis of the cross between PI 54608-1 ( $\alpha$-slow-type) and PI 90763 $\left(\alpha\right.$-low-type) showed no recombinant genotypes in the $\mathrm{F}_{2}$ segregation with respect to the subunit type and content : each of the $\mathrm{F}_{2}$ seeds with $\alpha_{\mathrm{s}^{-}}$and $\alpha$-subunits showed a normal content and a low content of the subunits, respectively. This implies that the factor(s) lowering the $\alpha$-subunit content would be strongly associated with the $\alpha$-subunit structural gene. In other words, the control of the $\alpha$-subunit content would be of the cis-regulation type rather than of the trans-regulation type as observed in the control of zein (maize storage protein) accumulation (SoAve and Salamini 1982).

Table 4. Observed and expected $F_{2}$ segregation from three crosses for the electrophoretic band of the $\beta$-conglycinin $\beta^{\prime}$-subunit

\begin{tabular}{|c|c|c|c|c|c|}
\hline \multirow{2}{*}{ Cross } & & \multicolumn{2}{|c|}{ Genotype } & \multirow{2}{*}{$\begin{array}{c}\chi^{2} \\
(3: 1)\end{array}$} & \multirow{2}{*}{$\mathrm{P}$} \\
\hline & & $C g y_{3}-$ & $c g y_{3} \operatorname{cg} y_{3}$ & & \\
\hline \multirow[t]{2}{*}{ B. } & Obs. & 108 & 36 & 0 & 1.0 \\
\hline & Exp. & 108 & 36 & & \\
\hline \multirow[t]{2}{*}{ C. } & Obs. & 104 & 40 & 0.59 & 0.3 \\
\hline & Exp. & 108 & 36 & & \\
\hline \multirow[t]{2}{*}{ D. } & Obs. & 143 & 37 & 1.89 & 0.1 \\
\hline & Exp. & 135 & 45 & & \\
\hline
\end{tabular}

The $F_{1}$ seeds from the crosses between $\beta^{\prime}$-type and common-type ( $\beta^{\prime}$-less) (Table 2 B, C and D) contained the $\beta^{\prime}$-polypeptide (Fig. 4), and the $F_{2}$ seeds segregated in a ratio of $3: 1$ (present : absent) (Table 4). These results indicate that the presenceof the $\beta^{\prime}$-subunit is controlled by an allele designated as $C g y_{3}$ at a single locus. This allele is dominant to the allele for the lack of the subunit, designated as $c g y_{3}$. No $\beta^{\prime}$-subunit was detected in the homozygous recessive $\operatorname{cg} y_{3} \operatorname{cg} y_{3}$.

\section{Inheritance of glycinin}

The $F_{1}$ seeds from the three crosses between A(I)-common-type $\times A(I)$-slow- and $A(I)$-fast-type (Table $2 \mathrm{D}, \mathrm{E}$ and $\mathrm{G}$ ) showed patterns overlapping with all the glycinin group- I acidic subunits of the two patterns. No recombinant types of the glycinin group- $I$ acidic subunits were obtained in the $F_{2}$ seeds from the three crosses. Only three banding patterns segregating in a $1: 2: 1$ ratio of one parent: $F_{1}$ : the other parent patterns were observed (Fig.4, Table 5). Furthermore the inheritance of the glycinin group- $I$ acidic subunits from the cross between the A(I)-common-type and the $A(I)$-fast-type (Table $2 \mathrm{G}$ ) was investigated using $F_{3}$ seeds produced by the $\mathrm{F}_{2}$ seeds with known phenotypes by AU-slab PAGE analysis of a part of cotyledons (Table 5). Segregation of the $F_{3}$ seeds followed the expected $1: 2: 1,1: 0$, and $0: 1$ ratios for heterozygous, homozygous dominant, and homozygous recessive geneotypes. of the $\mathrm{F}_{2}$ seeds, respectively (Table 6 ). 
Table 5. Observed and expected $F_{2}$ segregation from three crosses for the electrophoretic banding patterns of the glyciningroup-I acidic subunits

\begin{tabular}{|c|c|c|c|c|c|c|}
\hline \multicolumn{2}{|c|}{ Cross } & \multicolumn{3}{|c|}{ Genotype } & \multirow[t]{2}{*}{$\chi^{2}$} & \multirow[t]{2}{*}{$P$} \\
\hline & & $G y_{\mathrm{I}}^{\mathrm{a}} G y_{\mathrm{I}}^{\mathrm{a}}$ & $G y_{\mathrm{r}}^{\mathrm{a}} G y_{\mathrm{I}}^{\mathrm{b}}$ & $G y_{\mathrm{I}}^{\mathrm{b}} G y_{\mathrm{I}}^{\mathrm{b}}$ & & \\
\hline \multirow[t]{2}{*}{ D. } & Obs. & 43 & 92 & 45 & \multirow[t]{2}{*}{0.13} & \multirow[t]{2}{*}{0.9} \\
\hline & Exp. & 45 & 90 & 45 & & \\
\hline \multirow[t]{3}{*}{ E. } & Obs. & 12 & 18 & 13 & \multirow[t]{3}{*}{ 1. 19} & \multirow[t]{3}{*}{0.3} \\
\hline & Exp. & 10.75 & 21.5 & 10.75 & & \\
\hline & & $G y_{\mathrm{I}}^{\mathrm{a}} G y_{\mathrm{I}}^{\mathrm{a}}$ & $G y_{\mathrm{I}}^{\mathrm{a}} G y_{\mathrm{I}}^{\mathrm{c}}$ & $G y_{I^{\mathrm{c}}}^{\mathrm{c}} G{y_{\mathrm{I}}}^{\mathrm{e}}$ & & \\
\hline \multirow[t]{2}{*}{ G. } & Obs. & 21 & 53 & 30 & \multirow[t]{2}{*}{1.60} & \multirow[t]{2}{*}{0.3} \\
\hline & Exp. & 26 & 52 & 26 & & \\
\hline
\end{tabular}

Table 6. $\quad F_{3}$ segregation data from the cross of Keburi $\times$ Moshidou Gong 503 for the electrophoretic banding patterns of the glycinin group- $I$ acidic subunits

\begin{tabular}{|c|c|c|c|c|}
\hline \multicolumn{2}{|c|}{$F_{2}$ parents } & \multicolumn{3}{|c|}{$\mathrm{F}_{3}$ seeds } \\
\hline Phenotype & No. of plants & $G y_{\mathrm{I}}^{\mathrm{a}} G y_{\mathrm{r}}{ }^{\mathrm{a}}$ & $G y_{\mathrm{I}}{ }^{\mathrm{a}} G y_{\mathrm{I}}{ }^{\mathrm{e}}$ & $G y_{\mathrm{I}}{ }^{\mathrm{e}} G y_{\mathrm{I}}{ }^{\mathrm{c}}$ \\
\hline$G y_{\mathrm{I}}^{\mathrm{a}} G y_{\mathrm{I}}^{\mathrm{a}}$ & 21 & 252 & $3^{1)}$ & 0 \\
\hline$G y_{\mathrm{I}}^{\mathrm{a}} G y_{\mathrm{I}}^{\mathrm{c}}$ & 53 & $169^{2)}$ & $301^{2)}$ & $152^{2}$ \\
\hline$G y_{1}^{\mathrm{c}} G y_{\mathrm{I}}^{\mathrm{c}}$ & 30 & 0 & $5^{1)}$ & 358 \\
\hline
\end{tabular}

1) Contamination or outcrossing

2) $\chi^{2}$ for $1 G y_{\mathrm{I}}^{\mathrm{a}} G y_{\mathrm{I}}^{\mathrm{a}}: 2 G y_{\mathrm{I}}^{\mathrm{a}} G y_{\mathrm{I}}^{\mathrm{c}}: 1 G y_{\mathrm{I}}^{\mathrm{c}} G y_{\mathrm{I}}^{\mathrm{c}}=1.51 \mathrm{P}>0.3$

From the above results, it is concluded that the genes controlling the $A_{1}, A_{2}$ and $A_{3}$ subunits of glycinin are tightly linked and inherited like a single gene. The gene symbols $G y_{\mathrm{r}}^{\mathrm{a}}, G y_{\mathrm{I}}^{\mathrm{b}}$ and $G{y_{\mathrm{I}}}^{\mathrm{c}}$ were assigned to the alleles for the common, the slow and the fast electrophoretic forms of the group-I acidic subunits, respectively. Thus, the gene symbol $G y_{I}$ refers to a complex of the genes controlling the $A_{1}, A_{2}$ and $A_{3}$ subunits and probably the basic subunits specifically associated with $A_{1}, A_{2}$ and $\mathrm{A}_{3}$ because each of the glycinin polypeptides was translated as a precursor consisting of a signal sequence, an acidic and a basic polypeptide. A similar linkage was reported for some other legume storage protein (e.g., phaseolin and legumin) genes (BRown et al. $1981 \mathrm{~b}$, MAtTa and Gatehouse 1982).

\section{Linkage relationships among storage protein genes}

The data on the segregation of the five loci were paired for testing the linkage relationships. Linkage was found between $C g y_{2}$ and $C g y_{3}$. The chi-square value for independence was 310.3 which indicates a probability as low as 0.001 (Table 7), and $288 \mathrm{~F}_{2}$ progenies from the two crosses between $\alpha$-slow-type and $\beta^{\prime}$-type (Table $2 \mathrm{~B}$ and $\mathrm{C}$ ) contained no recombinant types of $\alpha$ - and $\beta^{\prime}$-subunits, suggesting that the two loci are closely linked. A similar linkage was reported by DAvies et al. (1985). In preliminary investigations, in the cross between Keburi and Moshidou Gong 503 we reported that there was a significant correlation between the $\alpha$ - and $\beta$-subunit contents, suggesting that the two genes controlling the $\alpha$ - and $\beta$-subunit products are closely linked together (TSukAda et al. 1984). From these results, we propose 
Table 7. $F_{2}$ segregation data from seven gene pairs of the dihybrid for good-of-fit to the $9: 3: 3: 1$ segregation ratio

\begin{tabular}{|c|c|c|c|c|c|c|c|c|}
\hline \multirow{2}{*}{ Cross } & \multirow{2}{*}{ Gene pair } & \multicolumn{4}{|c|}{ Observed frequencies of genotype $\mathrm{e}^{1)}$} & \multirow{2}{*}{ Total } & \multirow{2}{*}{$\chi^{2}$} & \multirow{2}{*}{$\mathrm{P}$} \\
\hline & & $A-B-$ & $A-b b$ & $a a B-$ & $a a b b$ & & & \\
\hline A & $C g y_{1}^{3)}-C g y_{2}$ & 144 & 44 & 34 & 11 & 233 & 4.30 & $0.2 \sim 0.3$ \\
\hline G & $C g y_{1}-G y_{\mathrm{I}}$ & 58 & 23 & 16 & 7 & 104 & 1.30 & $0.7 \sim 0.8$ \\
\hline$B$ and $C^{2 l}$ & $\mathrm{Cg}_{\mathrm{y}}-\mathrm{Cg} y_{3}$ & 212 & 0 & 0 & 76 & 288 & 310.32 & $0 \sim 0.001$ \\
\hline E & $C g y_{2}-G y_{\mathrm{I}}$ & 23 & 9 & 7 & 4 & 43 & 0.95 & $0.8 \sim 0.9$ \\
\hline $\mathrm{C}$ and $\mathrm{F}^{2)}$ & $C g y_{2}-G y_{4}^{4}$ & 134 & 40 & 42 & 17 & 233 & 0.86 & $0.8 \sim 0.9$ \\
\hline $\mathrm{D}$ & $C g y_{3}-G y_{\mathrm{I}}$ & 102 & 39 & 33 & 6 & 180 & 3. 30 & $0.3 \sim 0.5$ \\
\hline C & $C g y_{3}-G y_{4}$ & 77 & 28 & 27 & 12 & 144 & 1. 24 & $0.5 \sim 0.8$ \\
\hline
\end{tabular}

1) $A$ and $B$ represent the first and second loci of each gene pair.

2) The data combined.

3) $C g y_{1}:$ gene symbol of the $\beta$-conglycinin $\alpha^{\prime}$-subunit.

4) $G y_{4}$ : gene symbol of the glycinin $A_{5}$ subunit and its associated basic subunit.

that these three genes which control the $\alpha-, \beta-$ and $\beta^{\prime}$-subunit products should be located on the same chromosome.

Chi-square tests of all the other 6 dihybrid segregations showed a good agreement with the expected $9: 3: 3: 1$ ratio (Table 7) : the $C g y_{1}$ locus controlling the $\beta$-conglycinin $\alpha$-subunit product (Kitamura et al. 1984) was found to be independent of the $C g y_{2}$ and $G y_{1}$ loci, while the $C g y_{2}$ and $C g y_{3}$ were independent of the $G y_{1}$ and $G y_{4}$ loci controlling the group- $I$ acidic $\left(A_{1}, A_{2}\right.$ and $\left.A_{3}\right)$ and the glycinin $A_{5}$ subunits, respectively. It is suggested that the $G y_{4}$ locus is independent of the $C g y_{1}$ locus. (Kitamura et al. 1984) and the $G y_{\mathrm{I}}$ locus (Toyokawa et al. unpublished data). Thesefindings indicate that four soybean storage protein genes, $C g y_{1}, C g y_{2}, G y_{1}$ and $G y_{4}$, are located separately on different chromosomes or the same chromosome at a distance of over 50 centimorgan, each.

Regarding the relationships among the known linkage groups (2, 5 and 9) and the storage protein genes detected in the present study, the following conclusion was. drawn. The $T i$ locus controlling the Kunitz trypsin inhibitor electrophoretic bands. in the linkage group 9 (Hildebrand et al. 1980) segregated independently of the $C g y_{1}, C g y_{2}, G y_{1}$ and $G y_{4}$ loci, while the $L_{1}$ locus controlling the pod color in thelinkage group 5 and the $P$ locus controlling the pubescence in the linkage group. 2 segregated independently of the $C g y_{1}$ and $G y_{\mathrm{I}}$ loci (unpublished data).

These linkage data on the storage protein genes, together with their utilization: as genetic markers, may contribute to the improvement of the nutritional quality of seeds along with detailed information on the linkage maps of soybean genes.

This study was supported by "Green Energy Program" of the Agriculture, Forestry" and Fisheries Research Council, GEP 86-II-6-4.

\section{Literature Cited}

Brown, J. W. S., Y. MA, F. A. BLISS and T. C. HALL 1981 a. Genetic variation in the subunits of globulin-1 storage protein of French bean. Theor. Appl. Genet. 59: 83 88 .

—, F. A. BLISS and T.C. HALL $1981 \mathrm{~b}$. Linkage relationships between genes controlling seed: proteins in French bean. Theor. Appl. Genet. $60: 251 \sim 259$. 
CASEY, R. 1979. Genetic variability in the structure of the $\alpha$-subunits of legumin from Pisum-A two dimensional gel electrophoresis study. Heredity $43: 265 \sim 272$.

and M. N. SHORT 1981. Variation in amino acid composition of legumin from Pisum. Phytochemistry $20: 21 \sim 23$.

DAvies, C.S., J. B. COATES and. N. C. NIELSEN 1985. Inheritance and biochemical analysis of four electrophoretic variants of beta-conglycinin from soybean. Theor. Appl. Genet. 71:351 358.

DAvis, B. J. 1964. Disc electrophoresis II. Method and application to human serum protein. Ann. N. Y. Acad. Sci. 121: 404 427.

DERBYSHIRE, E., D. B. WrighT and D. BOULTER 1976. Legumin and vicilin, storage proteins of legume seeds. Phytochemistry $15: 3 \sim 24$.

De JONG, W. W., A. ZWEers and L. H. COHEN 1978. Influence of single amino acid substitutions on electrophoretic mobility of sodium dodecyl sulfate-protein complexes. Biochem. Biophys. Res. Commun. $82: 532 \sim 539$.

Hall, T. C., MCleester, R. C. and F. A. Bliss 1977. Equal expression of the maternal and paternal alleles for the polypeptide subunits of the major storage protein of the Bean Phaseolus vulgaris L. Plant Physiol. 69 : 1122 1124.

HARADA, K., Y. TOYOKAWA and K. KITAMURA 1983. Genetic analysis of the most acidic $11 \mathrm{~S}$ globulin subunit and related characters in soybean seeds. Japan. J. Breed. $33: 23 \sim 30$.

HILdEbRAND, D.F., J. H. ORF and T. Hymowitz 1980. Inheritance of an acidic phosphatase and its linkage with the KUNITZ inhibitor in seed protein of soybeans. Crop Sci. 20:83 85.

HILL, J. E. and R. W. BREIDENBACH 1974. Proteins of soybean seeds I : Isolation and characterization of the major components. Plant Physiol. $53: 742 \sim 746$.

IYENGAR, R. B. and P. RAVESTEIN 1981. New aspects of subunit structure of soybean glycinin. Cereal Chem. $58: 325 \sim 330$.

KITAMURA, K. and K. SHIBASAKI 1975. Isolation and some physicochemical properties of the acidic subunits of soybean $11 \mathrm{~S}$ globulin. Agric. Biol. Chem. 39 : 945 951.

- T. TAKAGI and K. SHIBASAKI 1976. Subunit structure of soybean $11 \mathrm{~S}$ globulin. Agric. Biol. Chem. 40: 1837 1844.

- Y. TOYOKAWA and K. HARADA 1980. Polymorphism of glycinin in soybean seeds. Phytochemistry $19: 1837 \sim 1844$.

and N. KAIZUMA 1981. Mutant strains with low level of subunits of $7 \mathrm{~S}$ globulin in soybean (Glycine max Merr.) seed. Japan. J. Breed. 31:353 359.

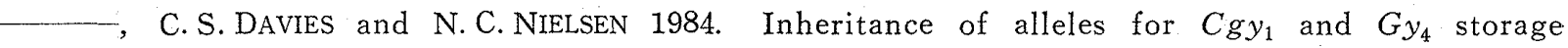
protein genes in soybean. Theor. Appl. Genet., $68: 253 \sim 257$.

LAEMMLI, U.K. 1970. Cleavage of structural proteins during the assembly of the head bacteriophage T 4. Nature $277: 680 \sim 685$.

MAHMOUD, S. H. and J. A. GATEHOUSE 1984. Inheritance and mapping of vicilin storage protein genes in Pisum sativum L. Heredity $53: 181 \sim 191$.

MAtTA, N.K. and J.A.GATEhouse 1982. Inheritance and mapping of storage protein genes in Pisum sativum L. Heredity $48: 383 \sim 392$.

Moreira, M. A., M. A. Hermodoson, B. A. LARkins and N. C. Nielsen 1979. Partial characterization of the acidic and basic polypeptides of glycinin. J. Biol. Chem. 254:9921 9926. polypeptides of glycinin. Arch. Biochem. Biophys. $210: 633 \sim 642$.

MORI, T., S. UTSUMI, H. INABA, K. KITAMURA and K. HARADA 1981 . Differences in subunit composition of glycinin among soybean cultivars. J. Agric. Food Chem. 29:20 23.

NOEL, D., K. NIKAIDO and G. F. AMES 1979. A single amino acid substitution in a histidine-transport protein drastically alters its mobility in sodium dodecyl sulfate-polyacrylamide gel electrophoresis. Biochemistry $18: 4159 \sim 4165$.

SCAllon, B., V.H. THANH, L. A. FloENER and N.C. NIELSEN 1985. Identification and characterization of DNA clones encoding group-II glycinin subunits. Theor. Appl. Genet. 70:510 519 .

SOAVE, C. and F. SALAMINI 1982. Zein proteins: a multigene family from maize endosperm. Qual. Plant. Plant Foods Hum. Nutr. $31: 191 \sim 203$.

THANH, V.H. and K. SHIBASAKI 1976. Heterogeneity of beta-conglycinin. Biochim. Biophys. Acta. $469: 326 \sim 338$.

and 1977. Beta-conglycinin from soybean proteins. Isolation and immunological and physicochemical properties of the monomeric forms. Biochim. Biophys. Acta. 490:370 
$\sim 384$.

TsUKADA, Y., K. KitAMURA, N. KaIZUMA and K. HARADA 1984. Studies on qualitative improvement of soybean seed proteins. 4. Inheritance and genetic linkage of $7 \mathrm{~S}$ globulins. Japan. J. Breed. 34(Supple. 1) : 140 141 (in Japanese).

TUMER, N. E., V. H. THANH and N. C. NIELSEN 1981. Purification and characterization of mRNA from soybean seeds: identification of glycinin and $\beta$-conglycinin precursors. J. Biol. Chem. 256 : $8756 \sim 8760$.

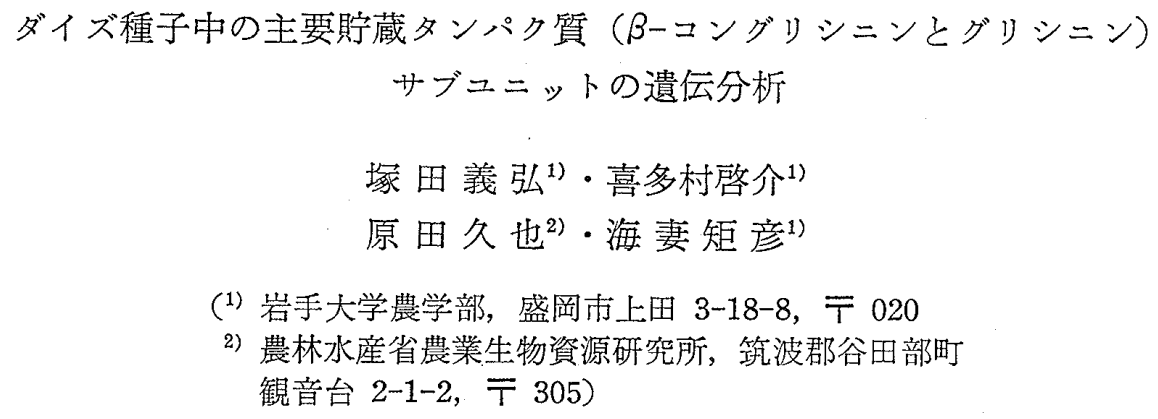

ダイズ種子貯蔵タンパク質には， $\beta$-ュングリシニンとグリシニンの 2 つの主要成分が含妾れ，その食品化学 的拉よび物理化学的性質が広く研究されている。しかし，他の豆類の貯蔵タンパク買に比べ，ダイズの貯蔵タ ンパク質サブニニットの遺伝様式や連鎖関係に関しては，あまり知られていない。

本研究は，この 2 主要貯蔵タンパク質サブニニット変異を探索し，見い出された変異の遺伝様式とそれらの 遗伝子座間の連鎖関係を明らかにしようとした。

ダイズ 850 品種・系統を， $\beta$ ーングリシニンとグリシニンの変異を探索するために，それぞれ SDS-ゲル電 気泳動とアルカリ側尿素系電気泳動で分析した。その結果， $\beta$-コングリシニンの $\alpha$ サブニニットに 2 つの変異

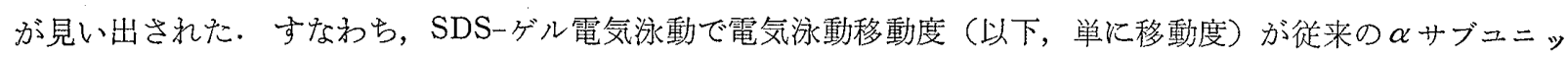
トの移動度よりもわずかに遅いバンドを示すタイプ（ $\alpha$-slow-type）と， $\alpha$ サブニニット生産量が低下したタイ プ $(\alpha$-low-type $)$ である.これらの変異は, 単一來の共優性対立遺伝子に上ることが示され，従来の $\alpha$ サブユ ニットの生産を支配する遺伝子拈よびそれよりる移動度の遅い

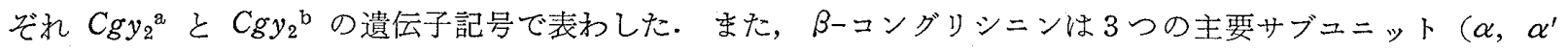
拉よび $\beta$ ) から成るとされていたが， $\beta$ サブニニットよりも移動度が速いるら一本の主要バンドを有する変異

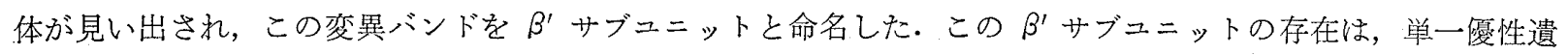
伝子 $\left(C g y_{3}\right)$ 江支配され, この遺伝子の劣性ホモ $\left(c g y_{3} c g y_{2}\right)$ によ $\beta^{\prime}$ サブニニットの欠失を生じることが示 された。

アルカリ側尿素系電気泳動でのグリシニン酸性サブニニットの変異に関しては， $A_{1}, A_{2}$ 拉よび $A_{3}$ サブュニ ットの移動度が同時に遅いタイプ (A(I)-slow-type) と速いタイプ (A(I)-fast-type) とが見い出された。 $\mathrm{F}_{2}$

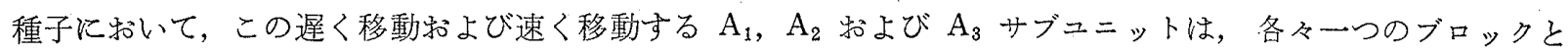
して挙動した。これらの変異性は，あたかも単一座の共優性対立遺伝子に支配されているょらに考劣られ，従 来の移動度を示す $A_{1}, A_{2}$ 䄧よび $A_{3}$ サブニニットの生産を支配する遗伝子， A(I)-slow-type の生産を支配 する遺伝子执よび $\mathrm{A}(\mathrm{I})$-fast-type の生産を支配する遺伝子をそれぞれ $G y_{\mathrm{I}}{ }^{2} ， G y_{\mathrm{I}}{ }^{\mathrm{b}}$ 抒よび $G y_{\mathrm{I}}{ }^{\mathrm{c}}$ の遺伝子記 号で表わした。

これらの遺伝子座や既知のダイズ種子貯蔵タンパク質遺伝子座間の連鎖関係を分析した結果, $C g y_{2}$ 座と $C g y_{3}$ 座との間に組換光型種子が得られなかったことからこれら 2 座が強く連鎖しているものと考兄られた。また， ほかの遺伝子座間の組合せでは独立に遺伝することが示された。 